\title{
PITUITARY GLAND IMPLANTATIONS IN RHEUMATOID ARTHRITIS
}

\author{
BY \\ GUNNAR EDSTRÖM, M.D. \\ From the Arthritis Clinic and Department of University Hospital, Lund, Sweden
}

A report from the Arthritis Department in Lund (Edström and Westman, 1942) dealt with a case of malignant rheumatoid arthritis in a 20-year-old woman with endocrine disturbances (primitive amenorrhoea and alopecia totalis). This woman was treated in the years 1939-40 with triply repeated implantations of the anterior part of calf pituitary glands. The arthritic process, which had proceeded uninterruptedly for three years in spite of all therapeutic attempts, underwent a change immediately after the second implantation, the first having been made three months earlier with a less pronounced effect: the exudation and perioedema of the affected joints subsided almost entirely during the days immediately following, there was a lessening of the tenderness and articular aching, and stiffness of muscles and joints as well as of the "feeling" of infection and of illness. The sedimentation rate fell during the next few weeks to normal values and the patient's humour, appetite, and body-weight all improved. This improvement continued for about five years. A slight deterioration lasting a few months then made its appearance, after which there was a further complete abatement of symptoms. During the 10-year period of observation from 1939 the malignancy of the process has not returned, even though the patient still exhibits deficient function in some joints, especially the wrists, on account of the earlier destruction of some cartilage- and bone-surfaces. The improvement in her endocrine status was not of so high a degree, two small haemorrhages occurring, but no regular menses; on the other hand, she has had since 1939 a good growth of hair on the head and in the axillae, where there had previously been none at all.

After studying the experience of Hench and others (1949) and of Thorn and others (1949) respecting the effect of injections of adrenocortical hormones and pituitary adrenocorticotrophic hormone on rheumatoid arthritis this method has again been employed in the Arthritis Department at Lund.

Since August 1949, pituitary gland implantations of this kind have been carried out in twenty-six cases of rheumatoid arthritis. All these have been mediumsevere, relatively fresh cases with a duratio morbis of from four months to four years. In one case use was made of the anterior part of a pituitary gland from a human foetus in the seventh gestational month; in all the others anterior parts of calf glands were employed, and two of these were implanted intragluteally at each operation, after being taken from the heads of the calves by a special sterile method, and so rapidly that not more than about 30 minutes elapsed from the calf's exitus 
to the implantation of the substance, cut into pieces, in the buttocks. The operations were performed by A. Sjövall and assistants at the Gynaecological Department, Lund. Healing took place by first intention in all cases except seven; in these a suppuration arose after a few days, but healed in a short time. No immediate suppuration arose in any case. The operations were carried out under local anaesthesia. One to three implantations were made on each subject. (A more detailed account of the technique will be given in another connexion.)

The immediate effect obtained, when there was any effect at all, manifested itself as regards the clinical status in the following fashion. Even during the first 24 hours after the implantation there was a marked reduction of stiffness in joints and muscles. After some days there set in an improvement of the articular and muscular function, diminished aching and pains of the joints on motion, as well as reduced tenderness, peri-oedema and swelling of the joints. The patients did not feel so ill and had a better appetite, the sedimentation rate diminished slowly, and the same observation was made as at the adrenocorticotrophic hormone (ACTH) medication, viz. a slight euphoria with increased mental capacity and activity. (Moving pictures which were taken show this better.)

During the first 24 hours following the implantation there was in most cases a markedly increased excretion of 17-ketosteroids in the urine, though the values had already returned to normal after 24 hours (see Figure). It is open to discussion whether the increased excretion depends on ACTH or the gonadotrophic hormones in the implantates, though the small amount of the latter could hardly be responsible for the amount of the increase. At the same time the number of eosinophil leucocytes in the circulating blood was observed to diminish, this condition also giving

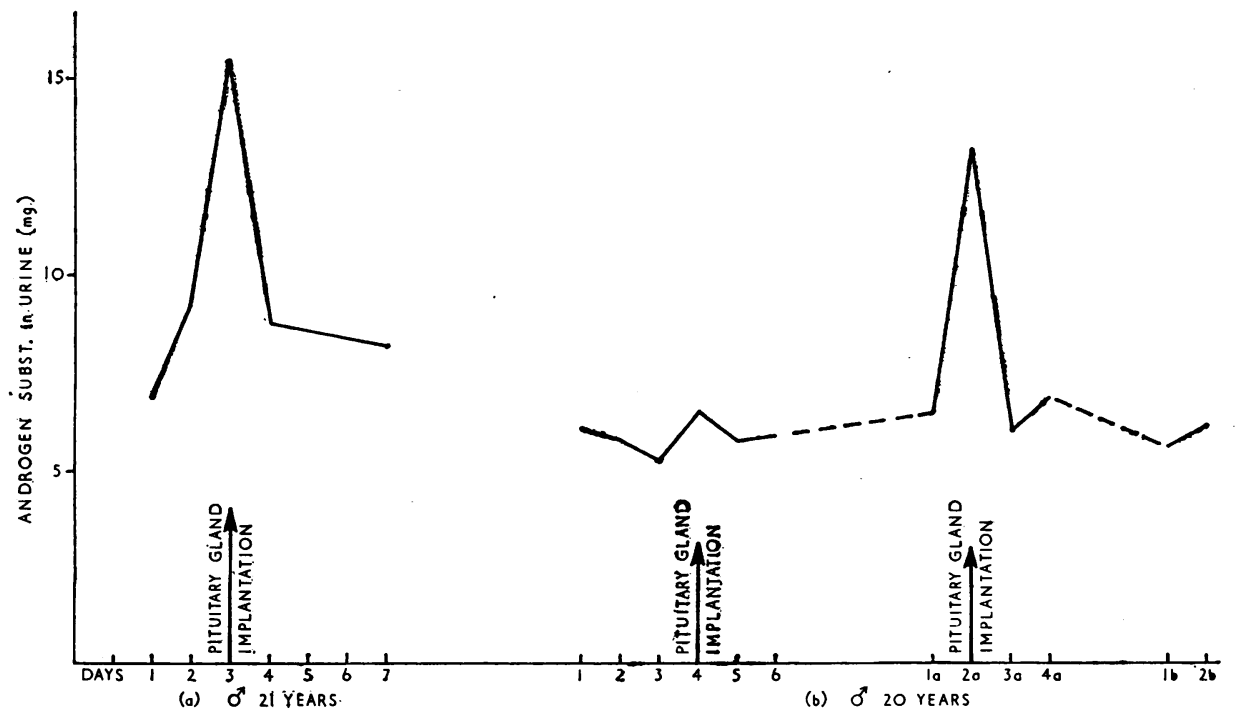

FiguRE.-Excretion of 17-ketosteroids before and after implantation of anterior parts of pituitary gland.

Case (a) man aged 21 years.

Case (b) man aged 20 years. 
place to normal values in a couple of days or so. No certain effect on the sodium, potassium, and chloride contents of the serum and on the plasma proteins has been observed.

In order to check that the operative trauma itself was not the active agent, a piece of brain without any pituitary body was also implanted under the same operative conditions. No effect was thereupon obtained on the clinical status, on the 17-ketosteroid excretion, or on the number of eosinophils in the circulating blood.

As Westman (1949) points out, in these pituitary gland implantations there can be no question of other than a transient hormonal shock or possibly of a shorttime action of a hormone depot. The idea of a transplantation effect cannot be entirely rejected, for, as Westman and Jacobsohn $(1940 ; 1942)$ have shown, the implanted pituitary glands are necrosed and absorbed rather quickly. That the hormonal effect thus obtained is of comparatively short duration and lasts for hardly more than a day, seems to be evident from our observations concerning the 17-ketosteroid excretion.

In this preliminary report it is as yet premature to express an opinion regarding any lasting effect that such an implantation may have upon the clinical status, the observation time being still too short for the majority of cases. In nine cases, however, the period of observation has been more than three months; an account of these cases is submitted in the following Table.

\section{EFFECT OF PITUITARY GLAND IMPLANTATIONS ON RHEUMATOID ARTHRITIS}

\begin{tabular}{|c|c|c|c|c|c|c|c|}
\hline \multirow{3}{*}{$\begin{array}{c}\text { Case } \\
\text { Nos. } \\
\text { (in order } \\
\text { of age) }\end{array}$} & \multirow{3}{*}{$\begin{array}{c}\text { Age } \\
\text { (years) }\end{array}$} & \multirow{3}{*}{ Sex } & \multirow{3}{*}{$\begin{array}{l}\text { Duratio } \\
\text { morbis }\end{array}$} & \multirow{3}{*}{$\begin{array}{l}\text { Number } \\
\text { of implan- } \\
\text { tations }\end{array}$} & \multicolumn{3}{|c|}{ Effect of implantations } \\
\hline & & & & & \multirow{2}{*}{$\begin{array}{l}\text { On clinical } \\
\text { state }\end{array}$} & \multicolumn{2}{|c|}{ On blood sedimentation rate } \\
\hline & & & & & & 1 hour before & 1 hour after \\
\hline $344-49$ & 20 & m. & 9 months & III & improved & 94 & 13 \\
\hline $334-49$ & 21 & m. & 4 months & II & $\begin{array}{l}\text { free from } \\
\text { clinical } \\
\text { symptoms }\end{array}$ & 23 & 10 \\
\hline $326-49$ & 25 & f. & 3 years & III & ," & 24 & 13 \\
\hline $312-49$ & 32 & f. & 1 year & II & ", & 22 & 14 \\
\hline $332-49$ & 36 & f. & 2 years & I & ", & 15 & 12 \\
\hline $337-49$ & 40 & f. & 4 years & III & ", & 39 & 26 \\
\hline $348-49$ & 40 & m. & 1 year & II & no effect & 34 & 67 \\
\hline $333-49$ & 45 & m. & 5 months & III & no effect & 90 & 82 \\
\hline $311-49$ & 51 & m. & 1 year & I & $\begin{array}{l}\text { free from } \\
\text { clinical } \\
\text { symptoms }\end{array}$ & 38 & 12 \\
\hline
\end{tabular}


Of the nine cases tabulated, six have been discharged from the department subjectively and objectively entirely free from symptoms in their joints, with a relatively normal sedimentation rate (between 10 and $14 \mathrm{~mm}$. per hour, except in one case having a rate of $26 \mathrm{~mm}$. per hour), and in good general condition. All these six patients are at their daily work. In two of these six (312 and 332) relapses have now occurred a little more than three months after the last implantations, but during that period of three months they were totally free from symptoms. Of the remaining three, one (344) has shown a considerable improvement, with diminished tenderness and stiffness in muscles and joints, less exudation and peri-oedema of the joints, no pain, and disappearance of a severe flexion contracture of the knee-joint, so that he is able to walk and run without trouble. His general condition is considerably better and his sedimentation rate has dropped from 94 to $13 \mathrm{~mm}$. per hour, though he is not wholly free from symptoms. In the other two cases (333 and 348), men of respectively 40 and 45 years, no effect has been observed.

The immediate clinical effect in the seventeen other cases (not tabulated) is that nine have been totally free from clinical symptoms, and four have shown no effect.

An interesting observation is that in all the younger cases-under 40 yearsa good clinical effect was obtained, while in the older cases the effect was not so pronounced. This is reminiscent of the experiments on rats of Silberberg and Silberberg (1939a, b; 1940), in which pituitary gland implantation produced a proliferation of articular cartilage in young animals while in older animals the effect ended in a mild degeneration of this cartilage.

The demonstration that injected adrenocorticotrophic hormone is very quickly excreted in the urine (within some minutes) has brought about a change in its use, so that several daily injections are now administered. As a result it has been found that full effect is also attained with a few $\mathrm{mg}$. in each dose. That hormonal effect which is here obtained from these pituitary gland implantations appears to be produced by a hormone-depot effect from the implantate and seems to be equivalent to repeated small injections of this kind. In experiments with ACTH it has been found that the more injections given per day the lower both the single injection dose and also the total daily dose need be, in order to obtain full biological effect. This explains in its turn how the small amount of hormone contained in two injected calf pituitary glands can suffice to establish a biologically active hormonal effect for 24 hours or more.

The next question for discussion is how to explain that such a transient hormonal shock as is obtained from an implantation of this kind can produce a comparatively lasting effect on the clinical status. From the first reports relating to the effect of adrenocorticotrophic hormone in rheumatoid arthritis it seemed that it was relatively transitory in all cases, though it lasted at times some weeks after the conclusion of the treatment. All these cases, however, were selected malignant ones. Since that time milder cases also have been chosen for this treatment and it appears from the reports of Thorn and others (1949), Spies (1949), Markson and 
Plum (1949), as though more lasting effects have also been observed by them in the less serious cases.

As yet it is too early to decide whether the effects here reported will be lasting or not. In six-possibly seven-of the cases the improvement has persisted for three months. All these, however, are milder cases without bone and cartilage destruction. On the other hand, however, in the malignant case with a 10-year period of observation first cited the effect has lasted these ten years.

Westman (1949) has given an account of the latest results obtained in a series of 246 cases of endocrine disturbance in which pituitary gland implantations were made and which were all under observation for at least one year after termination of the treatment. There was a lasting effect in 68 cases. Nystrand (1947) and Kylin $(1937 ; 1943)$ report similar results, and similar results have also been obtained at other places in Sweden, although they have not been published.

One of the purposes of the pituitary hormones is, as we know, to give impulses to the more or less independent automatism of the other endocrine organs. A single pituitary hormone effect can therefore perhaps to some extent be likened to that obtained by winding the works of a clock; if it is a good clock it can continue to go quite a long time. Accidental causes may slacken the spring for a time. If these are overcome, the whole mechanism will come into good working order again.

What has thus far been found should stimulate further research. In addition, tests should be made to see whether further progress could be made with another implantation procedure, e.g. with combinations of adrenocorticotrophic hormone. Insulin chemistry has provided certain lines of guidance, but other paths are also conceivable. The use of implantation tablets of deoxycortone acetate (DOCA) in Addison's disease is a therapeutic gain of territory in certain morbid cases (Thorn and others, 1943; 1948). The conditions here may at times be analogous.

\section{Summary}

Ten years ago a twenty-year-old woman with malignant rheumatoid arthritis and endocrine disturbances was treated with implantations of the anterior part of calf pituitary glands with surprisingly good effect on the arthritis; the malignancy of the process has not returned during the ten-year period of observation.

Since August, 1949, twenty-six further cases of rheumatoid arthritis without endocrine disturbances have been so treated. All were relatively fresh cases of moderate severity. Nine have been observed for more than three months. Six were discharged from the Arthritis Department subjectively and objectively entirely free from symptoms in their joints, with a relatively normal sedimentation rate, a good general condition, and four of these are still employed in their daily work. One showed considerable improvement; two showed no effect. In all patients under $\mathbf{4 0}$ years the results have been good, but they are not so good in the older patients.

Where there was any beneficial result, it appeared immediately, and was similar to that exerted on the clinical state by ACTH medication: during the first 24 hours following the implantations there was a markedly increased excretion of 
17-ketosteroids in the urine and a decrease in the eosinophils in the circulating blood.

Controls were made with implantations of brain without any pituitary gland.

\section{REFERENCES}

Edström, G., and Westman, A. (1942). Z. Rheum., 5, 417.

Hench, P. S., Kendall, E. C., Slocumb, C. H., and Polley, H. F. (1949). Proc. Mayo Clin., 24, 167; $181 ; 277$.

Kylin, E. (1937). Acta med. scand., 91, 428.

(1943). Svenska Läkartidn, pp. 574, 1612.

Markson, D. E. (1949). J. Amer. med. Ass., 141, 458.

Nystrand, F. (1947). Nord. Med., 35, 1481.

Plum, P. Personal communication.

Silberberg, M., and Silberberg, R. (1939). Arch. Path., 28, 340.

- - (1940). Anat. Rec., 78, 549.

Spies, T. D., and Stone, R. E. (1949). Sth. med. J., Nashville, 42, 720.

Thorn, G. W., Bayles, T. B., Massell, F., Forsham, P. H., Hill, S. R., Smith, S., and Warren, J. E. (1949). New Engl. J. Med., 241, 529.

—, Dorrance, S. C., and Day, E. (1942). Ann. intern. Med., 16, 1053.

-, Forsham, P. H., Prunty, F. T. G., and Hills, A. G. (1948). J. Amer. med. Ass., 137, 1005.

Westman, A. (1949). Nord. Med., 4, 1019.

—, and Jacobsohn, D. (1940). Acta path. microbiol. scand., 17, 328.

- — (1942). Ibid., 19, 34.

\section{Implantations de la Glande Pituitaire dans l'Arthrite Rhumatismale}

\section{RÉSUMÉ}

Il y a dix ans une femme de 20 ans souffrant d'une arthrite rhumatismale maligne accompagnée de troubles endocrines fut traitée par des implantations de la glande pituitaire antérieure de veau; l'effet favorable sur l'arthrite fut surprenant et au cours de dix années d'observation qui suivirent il n'y eut pas de rechute du processus maligne.

Depuis le mois d'août, 1949, on a traité de la même manière vingt-trois cas d'arthrite rhumatismale ne présentant pas de troubles endocrines. Tous ces cas furent relativement récents et modérément sévères. Neuf cas furent observés pendant plus de trois mois. Six furent renvoyés du Départment Arthrologique de Lund, débarrassés de tous les symptômes articulaires objectifs et subjectifs, avec leur sédimentation globulaire relativement normale et en bon état général; ils poursuivent encore leur occupation normale. Il y eut une amélioration considérable dans un cas; aucun effet dans deux cas. Chez tous les malades relativement jeunes (moins de 40 ans) les résultats furent bons, mais ils ne furent pas aussi bons chez les plus âgés.

Tout résultat favorable apparaissait immédiatement et il ressemblait à celui obtenu par suite de l'administration de l'hormone adrénocorticotrophique en ce qui concerne l'état clinique: pendant les 24 heures qui suivirent l'implantation il y eut une excrétion urinaire sensiblement accrue des 17-cétostéroides et une diminution des éosinophiles dans le sang circulant.

On implanta aix témoins des fragments de cerveau sans glande pituitaire.

\section{Implantaciones de la Glandula Pituitaria en la Artritis Reumatoide}

\section{RESUMEN}

Hace diez años una mujer de 20 años sufriendo de artritis reumática maligna con disturbios endocrinos fué tratada por implantaciones de la glándula pituitaria anterior de ternero; el efecto favorable fué sorprendente y durante los diez años de observación que siguieron el proceso maligno no volvió a repetirse.

Desde agosto de 1949 se ha tratado de la misma manera 23 casos de artritis reumatoide sin disturbios endocrinos. Todos los casos fueron bastante recientes y moderadamente severos. Nueve casos estuvieron bajo observación durante más de tres meses. Se ha dado de alta del Departamento de Artritis de Lund a seis de ellos, librados de todos síntomas articulares, objetivos y subjetivos, con la sedimentación globular relativamente normal y en buen estado general; todos continuan sus ocupaciones normales. Hubo una mejoría considerable en un caso, ningún efecto en dos. En todos los enfermos relativamente jóvenes (menos de 40 años) los resultados fueron buenos pero no lo fueron tanto en los más viejos.

Siempre que hubo un resultado favorable, éste aparecía inmediatamente y se parecía por el estado clínico a los obtenidos por la administración de la hormona adrenocorticotrófica: durante las 24 horas que siguieron la implantación hubo una excreción urinaria marcadamente acrecida de 17-cetosteroides y una diminución de los eosinófilos en la sangre circulante.

Se implantó a los testigos fragmentos de cerebro sin glándula pituitaria. 
(2) Le traitement au BAL réussit dans cinq cas sur six de réaction à l'or de date récente. Il fut aussi favorable dans quatre sur les autres cinq cas où la dermatite et les autres réactions à l'or étaient établies depuis plus longtemps. Le cas le plus ancien souffrait de sa dermatite due à l'or depuis trois mois, avec l'exanthème des jambes, du tronc, et des bras au stade de desquamation. Cinq heures après la première injection de BAL le prurit commença à céder; trois jours plus tard l'exanthème s'éclaircit pour disparaître entièrement au bout de dix jours.

(3) Le cas de réaction d'hypersensibilité au BAL avait aussi présenté sa dermatite à l'or depuis trois mois. Deux mois auparavant cette malade avait été traitée par de petites doses de BAL dans un autre hôpital-trop petites pour produire un effet thérapeutique. La réaction d'hypersensibilité apparut par suite d'un traitement répété au BAL.

(4) Dans quatre cas on observa une hématurie microscopique. Dans certains de ces cas l'hématurie fut un peu plus prononcée durant les premiers jours du traitement au BAL et disparut progressivement après.

(5) Des douleurs et des infiltrations passagères à l'endroit des injections furent observées dans la plupart des cas au premier jour du traitement; plus tard elles devinrent moins prononcées. On ne constata pas d'effets secondaires du BAL tels que céphalée, nausée, vomissements, sialorrhée, paresthésie, douleurs, ou crampes musculaires.

(6) Le traitement des réactions dues à l'or a accusé un grand progrès grâce au BAL, il est toutefois conseillé de s'en servir avec prudence.

\section{Efecto del 2,3-dimercapto-propanol (BAL) sobre la Reacciones debidas al Oro RESUMEN}

(1) Once casos de dermatitis y de otras reacciones debidas al oro fueron tratados por inyecciones intramusculares de BAL (2,3-dimercapto-propanol): con éxito, uno sin efecto, y en un caso hubo reacción de hipersensibilidad al BAL.

(2) Seis casos de reacciones al oro eran recientes y el tratamiento con BAL tuvo éxito en cinco de ellos. En los demás cinco casos la dermatitis y las otras reacciones debidas al oro habían existido desde algún tiempo y el efecto del tratamiento por BAL fué bueno en cuatro de ellos. El caso más antiguo había sufrido de su dermatitis debida al oro desde tres meses, con exantema de piernas, tronco, y brazos en el período de exfoliación. Cinco horas despuès de la primera inyección de BAL el prurito empezó a diminuir; tres días más tarde la erupción se aclareció para desaparecer enteramente dentro de diez días.

(3) El caso de reacción de hipersensibilidad al BAL había también presentado su dermatitis debida al oro desde tres meses. Dos meses antes esta enferma había recibido pequeñas dosis de BAL en otro hospital-demasiado pequeñas para producir efecto terapéutico. La reacción de hipersensibilidad resultó del tratamiento repetido por BAL.

(4) En cuatro casos hubo hematuria microscópica. En algunos de estos casos le hematuria fué algo pronunciada durante los primeros días del tratamiento por BAL, pero luego empezó a desaparecer.

(5) Dolores e infiltraciones transitorios en el sitio de las inyecciones fueron observados en la mayoría de los casos durante el primer día del tratamiento; luego se volvieron menos acentuados. No se vió efectos secundarios del BAL, tales como dolor de cabeza, náusea, vómitos, sialorea, parestesia, dolores, o calambres musculares.

(6) El tratamiento de las reacciones debidas al oro ha progresado mucho gracias al BAL, pero se aconseja prudencia en su empleo.

\section{CORRECTION}

Attention is drawn to the following error, which appeared in the Table to illustrate the article " Pituitary Gland Implantations in Rheumatoid Arthritis " by Gunnar Edström in the Annals of the Rheumatic Diseases, vol. 9, p. 22. The heading to the last two columns should read "Blood Sedimentation Rate per Hour, before Implantations and after Implantations ". 